\title{
B-Lynch suture technique to control postpartum hemorrhage in a patient with mullerian anomaly
}

\section{Uterin anomali olgusunda postpartum kanama kontrolünde B-Lynch sütür tekniği}

\author{
Ibrahim Hakan Boyar', Fazilet Kübra Boynukalın' ${ }^{1}$, Nuray Boyar ${ }^{1}$, Mehmet Vural ${ }^{2}$ \\ 'Department of Obstetrics and Gynecology, Şanluurfa Maternity Hospital, SSanluurfa, Turkey \\ 2Department of Obstetrics and Gynecology, Medical Faculty, Harran University, Şanluurfa, Turkey
}

\section{Abstract}

Congenital anomalies of the uterus may cause gynecologic, obstetric and fertility problems. Obstetrical complications are reported to occur more commonly with mullerian duct anomalies, such as postpartum hemorrhage (PPH). Uterine compression sutures may be effective in controlling PPH in these conditions as an alternative to hysterectomy, especially if the patient has a desire to conceive. As the shape of the uterus is changed in congenital malformation, the usage of compression sutures such as B-Lynch can be more difficult. In this study we report a case of PPH accompanying a large septae, treated with BLynch suture. A 24 year old, multigravid and nulliparous patient (G:3) was admitted to our clinic with vaginal bleeding and abdominal pain at 31 weeks of gestation. Emergency cesarean section was performed for abruptio placenta and PPH occurred subsequently. A deep uterine septum was revealed during operation. Intermittent fundal massage and intravenous uterotonics were used to improve uterine tonicity without any improvement. After the B-Lynch suture was performed, the bleeding diminished dramatically. As the shape of the uterus is changed in congenital malformation, the application of secondary interventions in postpartum hemorrhage can be more difficult. There can be slippage or overlapping of the suture while using a B-Lynch suture. Because the uterine shape is not completely distorted, patients with septate uterus can be candidates for a B-Lynch suture. There is no such reported case from the literature regarding efficacy of BLynch suture in mullerian anomalies. his case illustrates the potential benefits of B-Lynch compression suture in an uterus with mullerian anomalies.

(J Turkish-German Gynecol Assoc 2011; 12: 47-9)

Key words: Uterine anomaly, postpartum hemorrage, B-Lynch suture Received: 30 May, 2010

Accepted: 1 July, 2010
Özet

Uterin konjenital anomalileri jinekolojik ve obstetrik sorunlara yol açabilir ve infertilite ile bulgu verebilir. Postpartum kanama (PPK) ve erken doğum gibi obstetrik komplikasyonlar uterin anomalili olgularda daha sık karşımıza çıkar. Özellikle fertilite arzusu olan olgularda uterin kompresyon sütürleri postpartum kanamanın kontrolünde faydalı olabilir. Uterin anomalide uterusun şeklinin değişmiş olması etkin sütür konulmasını zorlaştırabilir. Bu çalışmada derin uterin septumu olan bir olguda B-Lynch sütürü ile PPK'nın etkin şekilde kontrolü değerlendirilmiştir. 24 yaşında G3P0A2 hasta 31 haftalık gebe iken hastanemize vajinal kanama şikayeti ile başvurdu. Hasta plasenta dekolmanı tanısıyla acil sezeryana alındı sezeryan sonrası PPK gelişti. İntraoperatif olarak derin uterin septum izlendi. Fundus masajı ve uterotonik ajanlara başvuruldu ancak yanıt alınamadı. B-Lynch sütürü konulduktan sonra kanama kontrol altına alındı. Uterusun şeklinin değişmiş olması nedeniyle kanamayı durdurmak amacıyla kullanılan ikinci basamak yöntemler zorlaşır. Uterusun şeklinin tamamen değişmemiş olduğu septat uterusta B-Lynch sütürü faydalı olabilir. Litaratürde uterin anomalili olgularda B-Lynch sütürünün etkinliğinin değerlendirildiği başka bir olgu sunumu bulunmamaltadır bu olgu sunumu ile uterin anomalili olgularda B-Lynch sütürü kullanılmasının etkin olabileceği gösterilmiştir.

(J Turkish-German Gynecol Assoc 2011; 12: 47-9)

Anahtar kelimeler: Uterin anomali, postpartum kanama, b-lynch sütürü

Geliş Tarihi: 30 Mayıs $2010 \quad$ Kabul Tarihi: 01 Temmuz 2010

\section{Introduction}

Congenital anomalies of the uterus are frequently asymptomatic and unrecognized. Mullerian duct anomalies can contribute to gynecologic, obstetric and fertility problems. The true incidence of mullerian duct anomalies is difficult to determine, because of the wide variation in presentation. They occur in approximately $3-4 \%$ of fertile and infertile women, $5-10 \%$ of women with recurrent early pregnancy loss, and up to $25 \%$ of women with late first or second-trimester pregnancy loss or preterm delivery (1-4). Obstetrical complications reported to occur more commonly with mullerian duct anomalies include increased risks of miscarriage, preterm delivery, intrauterine growth restriction, cervical incompetence, abnormal fetal presentation, pregnancy-associated hypertension, cesarean delivery, antepartum and postpartum hemorrhage (2, 5-8).

The most common cause of antepartum hemorrhage in the third trimester is placental abruption. Placental abruption is 
defined as decidual hemorrhage leading to the premature separation of the placenta prior to delivery of the fetus. Abruption of the placenta can lead to serious maternal and infant morbidity, as well as perinatal or maternal death. Management of women with severe placental abruption is surgical delivery (9). Also placental abruption can be complicated, with disseminated intravascular coagulopathy or postpartum hemorrhage due to uterine atony. Postpartum hemorrhage (PPH) is an obstetrical emergency that can follow vaginal or cesarean delivery. $\mathrm{PPH}$ is most commonly defined as having greater than $500 \mathrm{ml}$ estimated blood loss for vaginal delivery and 1000 for cesarean section. It is a major cause of maternal morbidity, and one of the top five causes of maternal mortality (10). The incidence of PPH varies 1 to 5 percent of deliveries $(10,11)$. If the initial management of controlling hemorrhage (fundal massage, uterotonic drugs) is not effective, secondary interventions (uterine tamponade procedures, compression sutures such as B-Lynch suture, uterine artery ligation, hypogastric artery ligation, x-ray guided artery embolisation and hysterectomy) should be considered.

If the patient has a desire to conceive, B-Lynch suture should be considered as an alternative to hysterectomy.

\section{Case}

A 24 year old, multigravid and nulliparous patient (G: 3) was admitted to our clinic with vaginal bleeding and abdominal pain at 31 weeks of gestation. She had had two previous miscarriages in the past. On examination the woman was conscious, oriented but pale. Her vital signs were normal except mild tachycardia (blood pressure: 100/60 $\mathrm{mmHg}$, heart rate: $96 / \mathrm{min}$, body temp: $36.6 \mathrm{C}$, respiratory rate: $22 / \mathrm{min}$ ). On abdominal examination her uterus was contracted and tender. Abdominal ultrasonography evaluation revealed a bradycardic fetus and a retroplacental hemorrhage. Fetal biometry was concordant with 31 weeks with normal amniotic fluid index. The fetus was in transverse situs. After diagnosis of ablatio placenta she was immediately transferred to the operating room. Cesarean section was performed with low segment transverse incision. A female, 1000 gr. infant was delivered (Apgar scores were 4 and 5 in first and fifth minutes respectively). Amniotic fluid was bloody and approximately $500 \mathrm{cc}$ fibrinated and defibrinated blood was drained from retro placental place. A deep uterine septum is revealed in the operation. Uterus was atonic and bleeding diffusely. Intermittent fundal massage and intravenous uterotonics used to improve uterine tonicity without any improvement. Because of worsening in homeostasis the compression suture technique of B-Lynch was performed with no 2 vicryl suture while uterine incision is open. Afterwards uterine incision was closed with continued locked sutures (Figure 1). After the practice, the patient's blood loss diminished to acceptable amounts. Intra-operative 2 units of red blood cells were given for replacement. Then the operation was finished. The patient was followed in intensive care unit postoperatively. After 12 hours her vital signs were normal and she was discharged in three days. Also postoperative weekly control was uneventful.

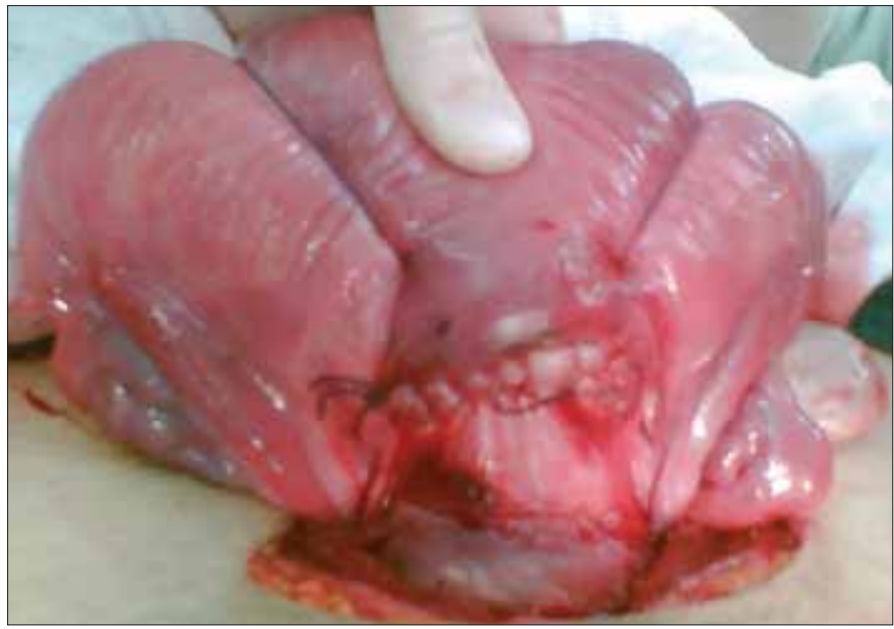

Figure 1. Performed B-Lynch suture in a septate uterus

\section{Discussion}

Postpartum hemorrhage is a common obstetric emergency which can lead to maternal morbidity and mortality. Surgical methods of controlling uterine bleeding by inserting compression sutures have been developed to reduce the incidence of emergency hysterectomy and to preserve fertility in these patients. B-Lynch suture is an alternative operative method for stopping postpartum hemorrhage especially in uterine atony. The chance for success of this procedure does not depend on surgical skill. With B-Lynch suture severe pressure can be achieved at the same time to both sides of uterine body. The suture provides enough compression without disturbing the anatomy. The B-Lynch suture compresses the uterus, similar to the result achieved with manual uterine compression. In case reports and small series it has successful in controlling postpartum hemorrhage caused by atony when other methods have failed. The advantage of this technique is simple to learn, safe and preserves future reproductive potential.

In a 7 year review of all uterine compression sutures for postpartum hemorrhage at one tertiary obstetric hospital, 27 B-Lynch sutures were performed. 10 patients needed additional compression suture techniques. All were done at the time of cesarean delivery. Hysterectomy was avoided in 23 of 27 women. 15 of these women were primiparous at the time of compression suture (12). In another study, Bhal and colloquies showed that, B-Lynch sutures were able to avoid hysterectomy 10 of 11 cases (13). In literature after uterine compression sutures, many successful pregnancies reported (14-16).

One fourth of women with late first or second trimester pregnancy lost or preterm delivery were associated with uterine malformations. The most common form of these malformations is septate uterus. As the shape of the uterus is changed in congenital malformation, the usage of secondary interventions in postpartum hemorrhage can be more difficult. There can be slippage or overlapping of the suture while using a B-Lynch suture. Halder A, reported a new uterine suture technique to control postpartum hemorrhage during cesarean section in congenitally malformed uterus. In his eight cases of series, hys- 
terectomy was avoided in 7 patients. Long term adverse effects have not been reported in these cases (17).

Our case was the most common form of uterine malformation which is septate uterus. Because the uterine shape is not completely distorted these patients can be a candidate for a B-Lynch suture. Although we had not any technical difficulty while placing B-Lynch suture to the uterus, worried about the failure of compression suture because of two reasons. Uterine surface was too large in width, compared to a normal postpartum uterus due to fusion defect and presence of a large septum could form a handicap for compressing the anterior and posterior walls each other. After applying procedure, the bleeding was diminished dramatically. There's no such reported case from the literature regarding efficacy of B-Lynch suture in mullerian anomalies. We can assert that B-Lynch suture can be an alternative for postpartum hemorrhage even in septate uterus avoiding hysterectomy.

\section{Conflict of interest}

None declared.

\section{References}

1. Acien P. Incidence of mullerian defects in fertile and infertile women. Hum Reprod 1997; 12: 1372-6.

2. Grimbizis GF, Camus M, Tarlatzis BC, Bontis JN, Devroey P. Clinical implications of uterine malformations and hysteroscopic treatment results. Hum Reprod Update. 2001; 7: 161-74. [CrossRef]

3. Raga F, Bauset C, Remohi J, Bonilla-Musoles F, Simón C, Pellicer A. Reproductive impact of congenital mullerian anomalies. Hum Reprod 1997; 12: 2277-81. [CrossRef]

4. Simón C, Martinez L, Pardo F, Tortajada M, Pellicer A. Mullerian defects in women with normal reproductive outcome. Fertil Steril 1991; 56: 1192-3.
5. Andrews MC, Jones HW Jr. Impaired reproductive performance of the unicornuate uterus: intrauterine growth retardation, infertility, and recurrent abortion in five cases. Am J Obstet Gynecol 1982; 144: 173.

6. Ben-Rafael, Z, Seidman, DS, Recabi, K, Bider, D. Uterine anomalies. A retrospective, matched-control study. J Reprod Med 1991; 36: 723.

7. Ludmir, J, Samuels, P, Brooks, S, Mennuti, MT. Pregnancy outcome of patients with uncorrected uterine anomalies managed in a high-risk obstetric setting. Obstet Gynecol 1990; 75: 906.

8. Heinonen, PK. Gestational hypertension and preeclampsia associated with unilateral renal agenesis in women with uterine malformations. Eur J Obstet Gynecol Reprod Biol 2004; 114: 39. [CrossRef]

9. Kayani, SI, Walkinshaw, SA, Preston, C. Pregnancy outcome in severe placental abruption. BJOG 2003; 110: 679. [CrossRef]

10. Mousa, HA, Alfirevic, Z. Treatment for primary postpartum haemorrhage (Cochrane Review). Cochrane Database Syst Rev 2003; CD003249.

11. Lu MC, Fridman M, Korst LM, Gregory KD, Reyes C, Hobel CJ et al. Variations in the incidence of postpartum hemorrhage cross hospitals in California. Matern Child Health J 2005; 9: 297-306. [CrossRef]

12. Baskett TF. Uterine compression sutures for postpartum hemorrhage: efficacy, morbidity, and subsequent pregnancy. Obstet Gynecol. 2007; 110: 68-71. [CrossRef]

13. Bhal K, Bhal N, Mulik V, Shankar L. The uterine compression suture--a valuable approach to control major haemorrhage at lower segment caesarean section. J Obstet Gynaecol. 2005; 25: 10-4. [CrossRef]

14. Sentilhes L, Gromez A, Trichot C, Ricbourg-Schneider A, Descamps P, Marpeau L. Fertility after B-Lynch suture and stepwise uterine devascularization. Fertil Steril. 2009; 91: 5-9.

15. Habek D, Vranjes M, Bobić Vuković M, Valetić J, Krcmar V, Simunac J. Successful term pregnancy after B-Lynch compression suture in a previous pregnancy on account of massive primary postpartum hemorrhage. Fetal Diagn Ther. 2006; 21: 475-6. [CrossRef]

16. Api M, Api O, Yayla M. Fertility after B-Lynch suture and hypogastric artery ligation. Fertil Steril. 2005; 84: 509. [CrossRef]

17. Halder A. A new uterine suture technique to control PPH in congenitally malformed uterus during caesarean section. J Obstet Gynaecol. 2009; 29: 402-4. [CrossRef] 